Jurnal Pemikiran \& Penelitian Psikologi

\title{
PSIKOLOGIA
}

p-ISSN: $185-0327$

e-ISSN: 2549-2136

www.jurnal.usu.ac.id/psikologia

\section{HUBUNGAN PERSEPSI KESELARASAN BUDAYA DENGAN STRATEGI AKULTURASI ETNIS LOKAL TERHADAP ETNIS TIONGHOA DI MEDAN}

\section{THE RELATIONSHIP BETWEEN PERCEPTION OF CULTURAL CONGRUENCE WITH ACCULTURATION STRATEGIES OF LOCAL ETHNIC TOWARDS CHINESE ETHNIC IN MEDAN}

Rani Febrina Ketaren dan Omar Khalifa Burhan

Psikologia: Jurnal Pemikiran \& Penelitian Psikologi

Tahun 2018, Vol. 13, No. 2, hal.120-131

Artikel ini dapat diakses dan diunduh pada:

www.jurnal.usu.ac.id/psikologia

\section{Dipublikasikan oleh:}

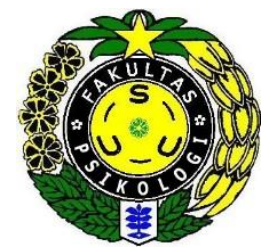

Fakultas Psikologi

Universitas Sumatera Utara

Jl. Dr. Mansyur No. 7 Medan. Telp/fax: 061-8220122

Email: psikologia@usu.ac.id 


\title{
HUBUNGAN PERSEPSI KESELARASAN BUDAYA DENGAN STRATEGI AKULTURASI ETNIS LOKAL TERHADAP ETNIS TIONGHOA DI MEDAN
}

\author{
Rani Febrina Ketaren dan Omar Khalifa Burhan \\ Universitas Sumatera Utara
}

\begin{abstract}
ABSTRAK
Pada penelitian ini, kami meneliti hubungan antara persepsi keselarasan budaya dengan preferensi strategi akulturasi etnis lokal terhadap Etnis Tionghoa di Medan. Hasil penelitian menunjukkan bahwa persepsi keselarasan budaya memiliki hubungan yang signifikan dengan strategi akulturasi. Artinya, semakin individu mempersepsikan bahwa budaya lokal dengan budaya Tionghoa tidak selaras maka individu tersebut akan cenderung melakukan strategi akulturasi ekslusi atau segregasi. Sedangkan individu yang mempersepsikan selaras antara budaya lokal dengan budaya Tionghoa maka individu akan cenderung melakukan strategi akulturasi multikultural atau asimilasi.
\end{abstract}

Kata kunci : persepsi keselarasan budaya, akulturasi, strategi multikultural, strategi asimilasi, strategi segregasi, dan strategi ekslusi.

\section{THE RELATIONSHIP BETWEEN PERCEPTION OF CULTURAL CONGRUENCE WITH ACCULTURATION STRATEGIES OF LOCAL ETHNIC TOWARDS CHINESE ETHNIC IN MEDAN}

\begin{abstract}
This study investigated the relationship between perceptions of cultural congruence with local ethnic's acculturation strategy towards Chinese Ethnic in Medan. The results showed that the perception of cultural congruence has a significant relationship with acculturation strategies. That is, the individual perceives that the local culture with Chinese culture is not congruence then the individual will tend to do the acculturation strategy of exclusion or segregation. The individuals perceive the congruence between the local culture with Chinese culture then the individual will tend to do the acculturation strategy multicultural or assimilation. This study also shows that the local culture is considered not congruence with the culture of immigrants is still a tendency for local ethnic to keep the distance with ethnic immigrants.
\end{abstract}

Keywords : perception of culture congruence, acculturation strategies, multicultural strategy, assimilation strategy, segregation strategy, and exclusion strategy

*Korespondensi mengenai penelitian ini dapat dilayangkan kepada: psikologia@usu..ac.id
Rekomendasi mensitasi:

Muslimah, R.N., Rahmawati, A. (2018). Gambaran Kualitas Hidup pada Wanita Dewasa Awal Penderita Kanker Payudara. Psikologia :Jurnal Pemikiran dan Penelitian Psikologi, 13(2), 120-131 
Indonesia merupakan negara yang terdiri dari kepulauan dan memiliki beragam etnik yang hidup berkembang dengan tradisi dan keyakinannya masing-masing. Beragam etnik ini tersebar di seluruh wilayah Indonesia, salah satunya di Provinsi Sumatera Utara. Menurut data BPS Medan (2012) jumlah penduduk kota Medan mencapai 2,8 juta orang dengan persentase jumlah etnis Jawa (33.2\%), Batak (24.11\%), Melayu (6.59\%), Minang $(8,6 \%)$, dan etnis lainnya $(7,89 \%)$. Selain etnis pribumi yang tinggal di daerah Medan, ada juga keturunan asing yang berkembang pesat di Medan yakni etnis Tionghoa dengan presentase $(10.65 \%)$.

Setiap etnik memiliki warisan budayanya masing-masing. Budaya merupakan cara hidup sekelompok orang (meliputi nilai-nilai, normanorma, dan cara pandang) yang berfungsi untuk memenuhi kebutuhan hidup kelompok tersebut (Berry, 1992; Baumeister, 2005). Individu yang merupakan bagian dari kelompok etnis tertentu akan berusaha menjaga dan melestarikan budaya kelompoknya. Akan tetapi, menurut beberapa peneliti budaya (dalam Hogg dan Vaughan, 2002), perbedaan budaya dapat menyebabkan konflik jika tidak ada toleransi antar budaya. Penting untuk bisa saling memahami satu dengan yang lainnya karena setiap kelompok yang hidup berdampingan dengan kelompok lain harus menjalani interaksi yang baik antar kelompok. Oleh sebab itu, proses adaptasi atau penyesuaian diri antara individu dari kelompok etnis yang satu dengan yang lainnya tidak dapat dihindari.

Proses interaksi antara individu yang berasal dari kelompok etnis yang berbeda mensyaratkan penyesuaian dan perubahan yang bersifat dua arah pada kelompok-kelompok etnis yang saling berinterkasi (Liebkind, 2001; Bourhis et al, 1997). Perubahan budaya yang terjadi ini disebut dengan akulturasi budaya. Akulturasi budaya dapat diekspresikan dalam bentuk perilaku (bahasa, pakaian, peran gender, strategi mendidik anak, atau afiliasi relegius) maupun diekspresikan secara internal atau psikologis (identitas pribadi, nilai, emosi, aspirasi, dan spiritualitas yang berdasarkan pada budaya). Berry dan Sam (2006), menyarankan sebuah model yang mengasumsikan bahwa dalam akulturasi, individu mengidentifikasikan diri dengan budaya yang satu atau yang lain, dengan keduanya, atau tidak dengan keduanya. Ada empat strategi akulturasi yaitu multikultural, asimilasi, segregasi, dan ekslusi. Setiap kelompok akan melakukan akulturasi hanya saja strategi yang digunakan berbeda-beda setiap kelompoknya.

Akulturasi budaya merupakan hasil dari interaksi yang terjadi antara dua kelompok etnis yang berbeda. Interaksi terjadi karena adanya proses adaptasi atau penyesuaian diri. Menurut Matsumoto (2008) adaptasi atau penyesuaian dengan budaya lain dapat terjadi ketika individu mengetahui apa yang harus diubah oleh individu tersebut. Pengenalan atau pemahaman individu terhadap budaya lainnya akan memunculkan penilaian terhadap budaya kelompok etnis yang berbeda tersebut sehingga penilaian ini akan membentuk sebuat persepsi. Persepsi merupakan proses pengelolaan dan pemberian makna pada sebuah stimulus. Persepsi yang akan muncul dari kedua kelompok etnis yang berinteraksi adalah persepsi selaras atau tidak selarasnya kedua budaya tersebut. Menurut Cameron dan Ettington (1988) keselarasan budaya berarti kesesuaian dalam budaya bukan sebuah keseragaman ataupun kesepakatan di antara kedua budaya yang berinteraksi. Persepsi keselarasan budaya adalah bentuk penilaian atau interpretasi dari kesesuaian komponen budaya (nilai-nilai, norma-norma, ataupun cara pandang) yang dirasakan oleh suatu kelompok dari budaya tertentu saat melakukan proses interaksi atau adaptasi dengan kelompok dari budaya lain. Persepsi akan keselarasan budaya dapat menghasilkan interaksi yang baik antara kedua kelompok. Tetapi ketika individu mempersepsikan bahwa adanya perbedaan budaya yang besar hal ini akan mengakibatkan munculnya ketidakselarasan budaya dan individu cenderung semakin ingin menjaga jarak dengan individu yang berasal dari kelompok yang berbeda (Vaughan, 2002). 
Daerah Sumatera Utara merupakan provinsi yang majemuk, yang terdiri dari beragam etnis, sehingga menuntut setiap individu untuk bisa saling berinteraksi dan saling menghargai budaya lain sehingga terciptalah hubungan yang baik. Perbedaan budaya juga menjadi tantangan bagi masyarakat kota Medan. Etnis Tionghoa merupakan etnis pendatang yang sangat berkembang sehingga jumlahnya cukup banyak di Sumatera Utara. Akan tetapi, penerimaan masyarakat kota Medan terhadap etnis Tionghoa belum sebaik penerimaan yang dilakukan masyarakat kota medan terhadap kelompok pendatang lainnya. Etnis Tionghoa yang tinggal di daerah Medan sangat menjaga kebudayaan yang mereka miliki. Mereka juga menjaga jarak dengan etnis lainnya di Medan. Hal ini dapat dilihat dari kehidupan sehari-hari, di mana mereka lebih suka menggunakan bahasa Hokkien dan sulit untuk berbahasa Indonesia. Penggunaan bahasa ini dilakukan dalam kehidupan sehari-hari ketika mereka saling berbicara satu sama lain dengan etnis mereka (Bangkaru, 2001). Hal ini disebabkan karena dari kecil mereka hidup di lingkungan etnisnya dan bersekolah di lingkungan yang mayoritas adalah etnisnya juga (Manurung \& Sudarwati, 2005). Fenomena ini merupakan indikasi bahwa etnis Tionghoa sedang menjaga jarak dengan etnis lainnya di Medan.

Namun, tidak dapat dipungkiri bahwa etnis lokal yang ada di Medan juga masih cenderung menjaga jarak dengan etnis Tionghoa. Menurut Burhan dan Sani (2013), etnis lokal juga masih memiliki prasangka terhadap etnis Tionghoa. Prasangka ini terjadi karena adanya ketakutan yang dirasakan etnis lokal bahwa keberadaan etnis Tionghoa merupakan ancaman terhadap nilai-nilai budaya yang dianut oleh etnis lokal. Selain itu, masih ada pandangan dari etnis lokal bahwa etnis Tionghoa masih tergolong eksklusif sehingga etnis lokal juga menjaga jarak dengan etnis Tionghoa.

"Awalanya saya sangat welcome dan dekat dengan mereka, namun lama-kelamaan mereka malah menunjukkan sikap tertutup dan

\begin{abstract}
membatasi pergaulan yakni hanya bergaul dengan sesame etnisnya saja, dan akhirnya saya benar-benar tidak menerima keberadaan mereka disini mengingat mereka bukan penduduk asli, namun malah mereka yang jauh lebih sombong daripada penduduk aslinya"

(Komunikasi Personal, 2014)

"Menurut saya, etnis Tionghoa tergolong eksklusif. Cenderung lebih bergaul dengan sesama Tionghoa dan memisahkan diri dari etnis lain"
\end{abstract}

(Komunikasi Personal, 2014)

Sikap yang ditunjukkan oleh etnis lokal terhadap etnis Tionghoa akan berdampak kepada perilaku etnis lokal. Perilaku-perilaku yang ditunjukkan oleh etnis lokal mengindikasikan bahwa sebenarnya etnis lokal belum menerima kehadiran etnis Tionghoa.

Penyesuaian dan perubahan budaya tidak hanya ditunjukkan oleh etnis pendatang tetapi penyesuaian dan perubahan budaya itu harus bersifat dua arah. Hal ini merupakan suatu syarat ketika individu yang berasal dari kelompok berbeda saling berinteraksi (Liebkind, 2001; Bourhis et al, 1997; Berry, 1990 dalam Bourhis et al 2009). Penyesuaian dengan budaya lain dapat terjadi ketika individu mengetahui apa yang harus diubah oleh individu tersebut (Matsumoto, 2008). Sehingga dalam hal ini etnis lokal harus mengetahui dan mengenal budaya dari kelompok etnis Tionghoa sehingga perubahan budaya dapat terjadi.

Berdasarkan uraian di atas, penelitian ini ingin melihat hubungan antara persepsi keselarsan budaya dengan strategi akulturasi yang dilakukan oleh etnis lokal terhadap etnis Tionghoa di Medan.

\section{AKULTURASI}

Interaksi antara individu yang berasal dari kelompok yang berbeda mensyaratkan penyesuaian dan perubahan yang bersifat dua arah 
pada kelompok-kelompok yang saling berinteraksi tersebut (Liebkind, 2001; Bourhis et al, 1997; Berry, 1990 dalam Bourhis et al 2009). Akulturasi merupakan sebuah perubahan budaya yang terjadi ketika anggota suatu kelompok masuk ke lingkungan baru yang di dalamnya terdapat kelompok lain (misal: penduduk lokal) yang telah mendiami tempat tersebut sebelum kedatangan kelompok pendatang (Redfield, Linton, dan Herskovits, 1963). Interaksi antara kelompok pendatang dengan kelompok lokal tersebut menyebabkan terjadinya penyesuaian dan perubahan perilaku dan psikologi, baik itu pada individu-individu kelompok pendatang, maupun pada individu-individu kelompok penduduk lokal (Sam \& Berry, 2006; Sam 2006). Penyesuaian dan perubahan yang terjadi diekspresikan dalam bentuk perubahan perilaku (bahasa, pakaian, peran gender, strategi mendidik anak, atau afiliasi religius) maupun diekspresikan secara internal (psikologis, seperti identitas pribadi dan sosial, nilai-nilai yang dianut, emosi, aspirasi, dan spiritualitas yang berdasarkan pada budaya).

Berdasarkan uraian di atas, definisi akulturasi dalam penelitian ini adalah penyesuaian dan perubahan perilaku dan psikologi yang terjadi pada individu, baik individu yang merupakan anggota kelompok pendatang maupun individu yang merupakan anggota kelompok penduduk lokal, sebagai dampak dari interaksi antara kedua kelompok yang terkait.

\section{PERSEPSI KESELARASAN BUDAYA}

Budaya merupakan cara hidup sekelompok orang (meliputi nilai-nilai, normanorma, cara pandang, dll), yang berfungsi untuk memenuhi kebutuhan hidup kelompok tersebut (Berry, 1992; Baumeister, 2005). Menurut Hogg dan Vaughan (2002) budaya mempengaruhi apa yang kita pikirkan, bagaimana kita merasa, apa prinsip moral dan nilai yang kita pegang, bagaimana kita berinteraksi dengan orang yang lainnya dan bagaimana kita mengerti dunia di sekitar kita.

\begin{abstract}
Keselarasan merupakan kesesuaian, ataupun keseimbangan. Persepsi keselarasan budaya adalah penilaian atau interpretasi individu bahwa adanya kesesuaian cara hidup (nilai-nilai, norma-norma, ataupun cara pandang) yang ada dalam suatu lingkungan masyarakat antara budaya yang satu dengan budaya lainnya. Keselarasan yang dimaksud adalah keselarasan dalam budaya saat melakukan interaksi, bukan keseragaman di antara subkultur atau kesepakatan di antara kedua budaya (Cameron \& Ettington, 1988). Berdasarkan uraian ini, kami mendefinisikan persepsi keselarasan budaya sebagai bentuk interpretasi individu mengenai kesesuaian yang dirasakan oleh suatu kelompok dari budaya tertentu saat melakukan proses interaksi atau adaptasi dengan kelompok dari budaya lain
\end{abstract}

Ketidakselarasan terjadi ketika anggota setiap kelompok tidak merasakan adanya kesesuaian budaya atau individu mempersepsikan bahwa perbedaan budaya kedua kelompok sangat besar. Studi sosial oleh Vaughan (2002) menunjukkan bahwa semakin dianggap berbeda suatu budaya, semakin orang ingin untuk menjaga jarak dari anggota kelompok budaya tersebut. Hal ini menyebabkan pembentukan kontak antar budaya menurun sehingga bisa menimbulkan persepsi negatif yang dapat memicu terjadinya konflik antar kelompok budaya. Oleh sebab itu, ketidakselarasan budaya dapat memicu terjadinya konflik antar kelompok budaya.

Dimensi-dimensi yang akan membentuk persepsi keselarasan budaya dapat dilihat dari komponen-komponen yang membentuk suatu budaya. Hal ini dapat dilihat dari faktor yang mempengaruhi budaya yakni yaitu faktor ekologikal, sosial, dan biological (Matsumoto,2008). Ketika faktor tersebut dapat membentuk aspek-aspek psikologis masyarakat. Secara spesifik, faktor-faktor tersebut dapat membentuk hal-hal sebagai berikut: 
a. Attitudes, berinteraksi dengan orang lain.

b. Value, nilai yang menyediakan informasi untuk melakukan suatu tindakan.

c. Beliefs, keyakinan/kepercayaan dasar tentang suatu hal

d. Opinions, alasan dibalik tindakan individu dan orang lain.

e. Worldviews, cara individu mempersepsikan dunia mereka.

f. Norms, norma yang disepakati berdasarkan aturan.

g. Behaviors, mempunyai dan mengekspresikan emosi.

\section{ETNIS TIONGHOA DAN ETNIS LOKAL DI MEDAN}

Penelitian ini menjelaskan bahwa yang menjadi etnis pendatang adalah etnis Tionghoa. Hal ini dikarenakan etnis Tionghoa merupakan salah satu etnis asing yang berpendatang ke wilayah Indonesia, termasuk wilayah Sumatera Utara. Walaupun saat ini etnis Tionghoa tidak lagi menjadi etnis asing tetapi sudah diakui sebagai salah satu etnis pribumi. Menurut Undang-Undang No. 12 tahun 2006 tentang persyaratan kewarganegaraan menyatakan bahwa tidak lagi ada diskriminasi terhadap etnis Tionghoa dalam hal kependudukan. Undang-Undang ini didukung oleh Undang-Undang N0. 40 tahun 2008 yang menghapus diskriminasi ras dan etnis. Namun dalam penelitian ini etnis Tionghoa merupakan kelompok pendatang.

Sedangkan yang menjadi kelompok lokal dalam penelitian ini adalah suku-suku pribumi asli Indonesia yang berdomisili di wilayan kota Medan, yakni suku Batak, Jawa, Melayu, Minang, Aceh, dan Nias, dengan persentase jumlah etnis Jawa (33.2\%), Batak (24.11\%), Melayu (6.59\%), Minang $(8,6 \%)$, dan etnis lainnya $(7,89 \%)$ (BPS Medan, 2012).

\section{PARTISIPAN}

Populasi penelitian merupakan individu yang menjadi sumber data penelitian. Menurut Azwar (2001) populasi merupakan sekelompok subjek yang hendak dikenai generalisasi dari hasil penelitian. Sekelompok subjek yang akan dikenai generalisasi tersebut terdiri dari sejumlah individu yang setidaknya mempunyai satu ciri atau karakteristik yang sama. Populasi dalam penelitian ini adalah masyrakat kota Medan. Karakteristik dari sampel yang akan diteliti adalah :

$\checkmark$ Etnis Batak, Jawa, Melayu, Minang dan lainnya yang berdomisili di Medan

$\checkmark$ Berusia 18 tahun sampai 50 tahun (dewasa awal sampai dewasa madya)

Jumlah partisipan dalam penelitian ini sebanyak 221 orang.

\section{TEKNIK PENGAMBILAN SAMPEL}

Teknik sampling adalah cara yang digunakan untuk mengambil sampel dari populasi dengan menggunakan prosedur tertentu dalam jumlah yang sesuai dengan memperhatikan sifat dan penyebaran populasi agar benar - benar mewakili populasi (Suryabrata, 2010). Teknik pengambilan sampel dalam penelitian ini bersifat accidental sampling dengan menggunakan teknik accidental sampling non probability yang berarti individu atau kelompok-kelompok yang kebetulan dijumpai atau dapat dijumpai saja yang diteliti dan populasi tidak memiliki peluang yang sama (Hadi, 2000). Keuntungan dari penggunaan metode ini adalah dapat menghemat waktu dan biaya penelitian. Akan tetapi, peneliti juga menyadari kelemahan dari teknik ini yakni tidak dapat memberikan tingkat keyakinan yang tinggi (Hadi, 2000). Oleh karena itu, salah satu upaya peneliti dalam meningkatkan keakuratan data yaitu meningkatkan jumlah responden penelitian dan menyimpulkan hasil penelitian hanya pada subjek penelitian yang terlibat.

\section{ALAT UKUR}


Penelitian ini menggunakan dua buah skala psikologi yaitu: persepsi keselarasan budaya dan strategi akulturasi etnis lokal terhadap etnis Tionghoa Masing-masing skala ini menggunakan skala model Force Choice. Skala terdiri dari dua pilihan jawaban, yakni setuju dan tidak setuju. Skala disajikan dalam bentuk pernyataan favourable (mendukung) dan unfavourable (tidak mendukung). Nilai setiap pilihan bergerak dari 1-0, bobot penilaian untuk pernyataan favorable yaitu Setuju $=1$ dan tidak setuju $=0$. Sedangkan untuk bobot pernyataan unfavorabel yaitu Setuju $=0$ dan tidak setuju $=1$.

\section{Persepsi Keselarasan Budaya}

Alat ukur persepsi keselarasan budaya yang digunakan dalam penelitian ini adalah skala yang dibuat oleh peneliti dengan mengacu kepada karakteristik psikologis yang diungkapkan oleh Matsumoto (2008). Skala ini memiliki rentang nilai dari 0 sampai $1(0=$ tidak sesuai $-1=$ sesuai). Jadi, semakin tinggi skor partisipan pada pengukuran persepsi keselarasan budaya maka semakin tinggi derajat persepsi keselarasan budaya yang ia miliki. Alat ukur ini terdiri dari 10 item. Dimana partisipan diminta untuk memilih "tidak sesuai" atau "sesuai". Nilai tertinggi adalah 10 dan nilai terendah adalah 0 .

\section{Tabel 1: Blue Print Skala Persepsi Keselarasan Budaya Sebelum Uji Reliabilitas}

\begin{tabular}{|c|c|c|}
\hline Karakteristik & Aitem & Jumlah \\
\hline Attitude & $\begin{array}{ll}4 & \text { dan } \\
7 & \end{array}$ & 2 \\
\hline Value & 2 & 1 \\
\hline beliefs & $\begin{array}{ll}1 & \text { dan } \\
5 & \end{array}$ & 2 \\
\hline Worldviews & 9 & 1 \\
\hline Norms & 3 & 1 \\
\hline behaviors & 6 dan & 2 \\
\hline
\end{tabular}

\section{8}

$\begin{array}{lll}\text { opinions } & 10 \quad 1\end{array}$

$\begin{array}{ll}\text { TOTAL } & 10\end{array}$

2. Skala Strategi Akulturasi Budaya

Strategi akulturasi budaya pada penelitian ini akan diukur dengan menggunakan skala yang disusun berdasarkan pada preferensi yang diajukan oleh Berry (1980, 1984), ada dua dimensi, yang akan menentukan strategi akulturasi, yakni: (1) Preferensi individu untuk mempertahankan budaya dan kontak antar kelompok dan (2) preferensi individu untuk berinteraksi dan membangun hubungan dengan anggota dari kelompok lainnya. Skala ini terdiri dari 20 aitem dengan dua pilihan jawaban yakni "tidak sesuai" atau "sesuai".

Skala peneliti ciptakan dengan mererata aitem untuk membentuk skala strategi akulturasi yang merentang dari 0 sampai 1 ( $0=$ tidak sesuai $-1=$ sesuai). Skor yang akan dihasilkan akan mengarahkan kepada strategi akulturasi yang digunakan oleh partisipan. Sebelum menentukan kategori dari variabel tergantung perlu diketahui median setiap dimensi dari variabel tergantung tersebut. Kemudian median ini akan menentukan nilai tinggi atau rendahnya sampel pada dimensi tersebut. Ketika nilai sampel berada diatas median maka sampel tersebut tinggi pada dimensi tersebut. Tetapi sebaliknya ketika nilai sampel berada dibawah median maka sampel tersebut rendah pada dimensi tersebut. Setelah mendapatkan nilai tinggi-rendahnya pada kedua dimensi ini, maka kami dapat mengkategorikan kedalam empat kategori strategi akulturasi, yakni sebagai berikut : 


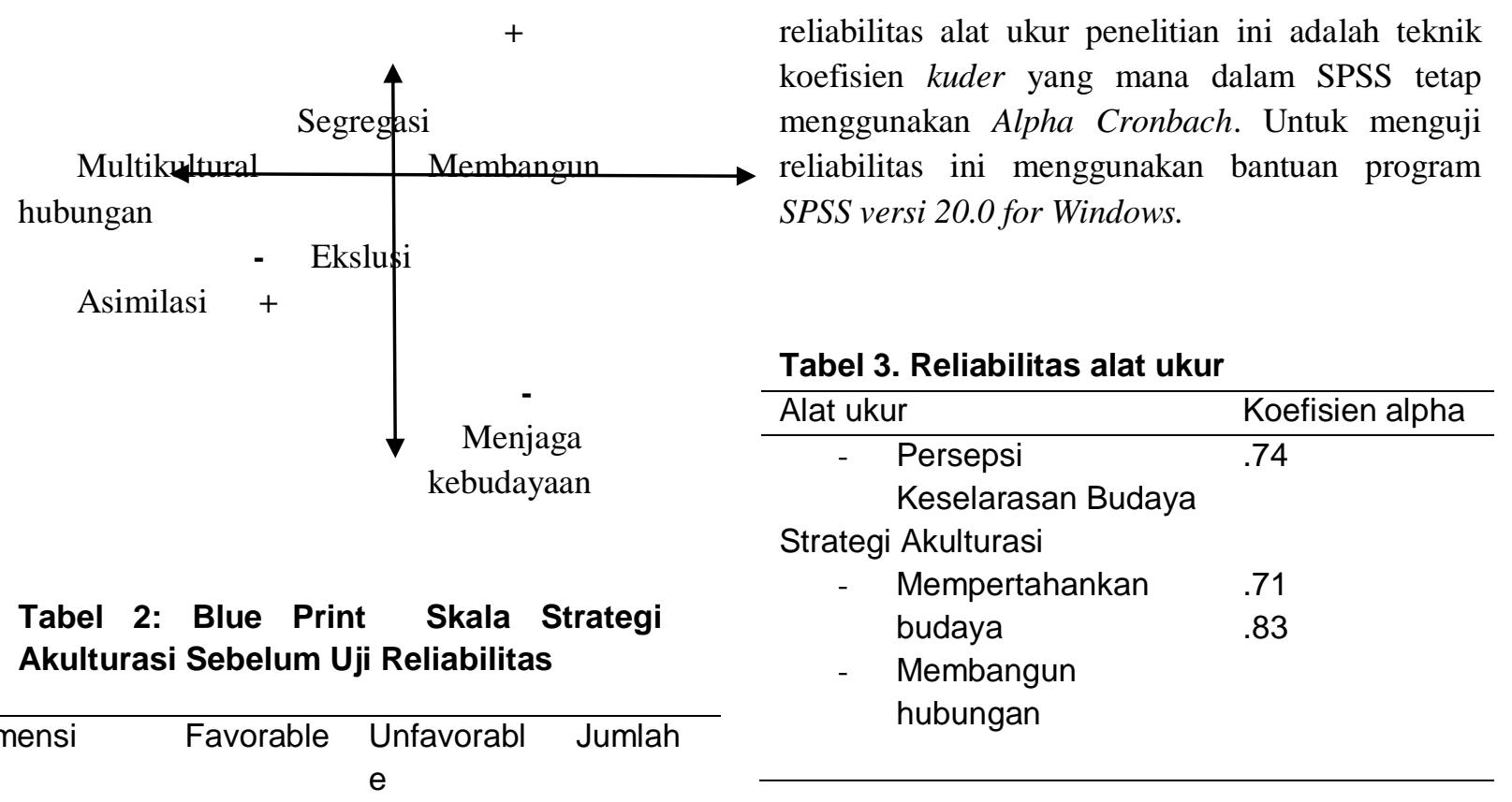

\begin{tabular}{llll}
\hline Dimensi & Favorable & $\begin{array}{l}\text { Unfavorabl } \\
\mathrm{e}\end{array}$ & Jumlah \\
\hline $\begin{array}{l}\text { Mempertaha } \\
\text { nkan budaya }\end{array}$ & $10,3,4,6$, & $1,5,7,8,9$ & 10 \\
& $11, \quad 13$, & $12,14,18$, & 10 \\
$\begin{array}{l}\text { Membangun } \\
\text { hubungan }\end{array}$ & $15,16,17$ & 19,20 & \\
TOTAL & & & 20 \\
\hline
\end{tabular}

\section{VALIDITAS DAN RELIABILITAS ALAT UKUR}

Validitas yang digunakan dalam penelitian ini adalah validitas isi (content validity). Validitas isi menunjukkan sejauhmana item-item dalam tes mencakup keseluruhan hal yang hendak diukur. Hal ini juga memiliki pengertian bahwa tes ini tidak hanya komprehensif tetapi isinya juga harus tetap relevan dan tidak keluar dari tujuan Tabel 4: Blue Print Skala Persepsi Keselarasan Budaya Setelah Uji Reliabilitas

\begin{tabular}{lll}
\hline Karakteristik & Aitem & Jumlah \\
\hline Attitude & 4 dan 7 & 2 \\
Value & 2 & 1 \\
Beliefs & 1 dan 5 & 2 \\
Worldviews & 9 & 1 \\
Norms & 3 & 1 \\
behaviors & 6 dan 8 & 2 \\
opinions & 10 & 1 \\
TOTAL & & 10 \\
\hline
\end{tabular}
pengukuran. Validitas isi diperoleh melalui pendapat profesional dari dosen pembimbing dan dosen yang memiliki kompetensi dalam bidang yang hendak diteliti (Azwar, 2010).

Reliabilitas alat ukur dapat dilihat dari koefisien reliabilitas yang merupakan indikator konsistensi aitem-aitem tes dalam menjalankan fungsi ukurnya bersama-sama (Azwar, 2010). Teknik yang digunakan untuk pengukuran 
Tabel 5: Blue Print Skala Strategi Akulturasi Budaya Setelah Uji Reliabilitas

\begin{tabular}{llll}
\hline Dimensi & Favorable & Unfavorable & Jumlah \\
\hline $\begin{array}{l}\text { Mempertahankan } \\
\text { budaya }\end{array}$ & $10,3,4,6,1,5,7,8,9$ & 10 \\
& $11,13,12,14,18,10$ \\
$\begin{array}{l}\text { Membangun } \\
\text { hubungan }\end{array}$ & $15,16,17 \quad 19,20$ & \\
TOTAL & & & 20 \\
\hline
\end{tabular}

\section{HASIL}

\section{Gambaran umum partisipan penelitian}

Partisipan dalam penelitian ini merupakan masyarakat kota Medan. Sampel penelitian berjumlah 221 orang yang terdiri dari 72 orang laki-laki dan 149 orang perempuan.

Tabel 6 : Data Partisipan Berdasarkan Usia

\begin{tabular}{ll}
\hline Usia & Jumlah \\
\hline $18-40$ tahun & 209 orang \\
$41-65$ tahun & 12 orang \\
\hline
\end{tabular}

Tabel 7 : Data Partisipan Berdasarkan Suku

\begin{tabular}{ll}
\hline Suku & Jumlah \\
\hline Batak & 140 orang \\
Jawa & 43 orang \\
Melayu & 20 orang \\
Padang & 14 orang \\
Lainnya & 4 orang \\
\hline
\end{tabular}

\begin{tabular}{ll}
$\begin{array}{l}\text { Tabel } 8 \text { : Data Partisipan Berdasarkan } \\
\text { Pekerjaan }\end{array}$ \\
\hline Pekerjaan & Jumlah \\
\hline Mahasiswa & 150 Orang \\
Wiraswasta & 18 Orang \\
Pegawai & 17 Orang \\
Belum bekerja & 16 Orang \\
lbu Rumah Tangga & 9 Orang \\
PNS & 9 Orang \\
Pekerja Sosial & 2 Orang \\
\hline
\end{tabular}

Peneliti berhipotesis ada hubungan antara strategi akulturasi dengan persepsi keselarasan budaya, semakin individu mempersepsikan budayanya selaras maka semakin tinggi kecenderungan individu untuk melakukan strategi akulturasi multikultural dan semakin individu mempersepsikan budayanya tidak selaras maka semakin tinggi kecenderungan individu tersebut untuk melakukan strategi akulturasi pada bentuk segregasi dan ekslusi. Hipotesis penelitian ini diujikan dengan menggunakan analisis multinominal logistic regresi. Multinominal logistic regresi digunakan untuk menyelesaikan kasus regresi dengan variabel tergantungnya berupa data kategorikal yang berbentuk multinominal ( $\geq 2$ katergori) dengan satu atau lebih variabel bebas. Dalam penelitian ini variabel tergantungnya adalah strategi akulturasi yang dikategorikan ke dalam empat kelompok, yaitu: multikultural, asimilasi, ekslusi, dan segregasi. Sedangkan variabel bebasnya adalah persepsi keselarasan budaya yang tidak dikategorikan sehingga variabel ini menjadi variabel covariat. Selain itu, statistika multinominal logistic regresi ini juga membandingkan kategori-kategori dari variabel tergantung ketika dihubungkan dengan variabel bebas. Maka harus ada satu kategori yang menjadi kelompok acuan dalam membandingkan kategori-kategori tersebut. Kelompok acuan ini menjadi kelompok pembanding yang nantinya akan menjelaskan kecenderungan perilaku dari subjek penelitian. Kelompok acuan dalam penelitian ini adalah strategi akulturasi multikultural, karena strategi akulturasi ini merupakan strategi akulturasi yang ideal dimana individu yang mempersepsikan budayanya selaras maka individu tersebut akan melakukan strategi ini.

Sebelum menentukan kategori dari variabel tergantung perlu diketahui median setiap dimensi (mempertahankan budaya dan membangun hubungan) dari variabel tergantung tersebut. Median dari dimensi mempertahankan budaya adalah 6 dan median dari dimensi membangun hubungan adalah 5. Jika nilai yang diperoleh dari setiap individu pada dimensi 
mempertahankan budaya lebih kecil dari 6 (median) maka individu tersebut rendah pada dimensi mempertahankan budaya dan sebaliknya. Sama halnya dengan dimensi membangun hubungan, jika nilai individu pada dimensi membangun hubungan di bawah 5 (median) maka individu tersebut rendah pada membangun hubungan dan sebaliknya. Setelah itu dikategorikan ke dalam empat strategi akulturasi dan didapatkan data sebagai berikut:

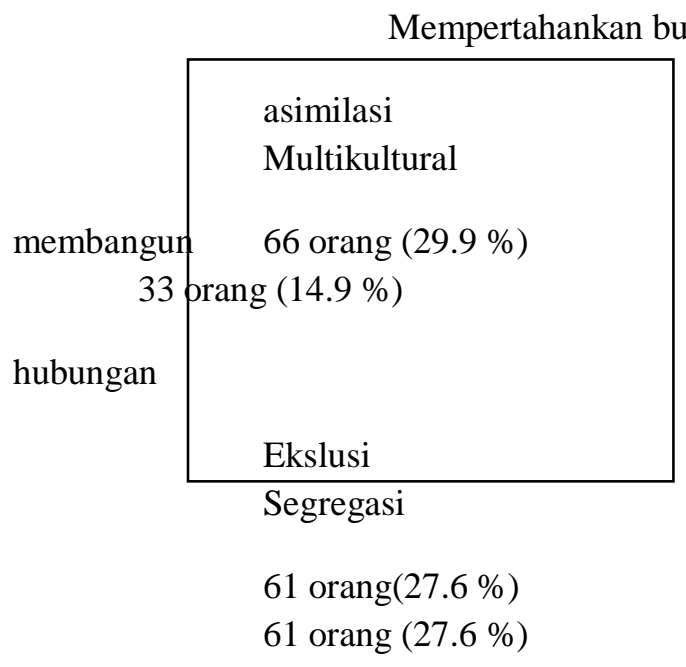

Sesuai dengan hipotesis yang diajukan, maka hasil penelitian ini adalah terdapat hubungan yang signifikan antara strategi akulturasi dengan persepsi keselarasan budaya, $\mathrm{p}$ $=0,002$. Secara spesifik, hasil menunjukkan bahwa semakin rendah persepsi individu terhadap keselarasan budaya maka individu akan cenderung untuk melakukan strategi akulturasi ekslusi ( $\mathrm{p}=0.024 \mathrm{~b}=-0.192$ ) dibandingkan dengan strategi akulturasi multikultural. Selain itu, semakin rendah persepsi individu terhadap keselarasan budaya maka individu akan cenderung untuk melakukan strategi akulturasi segregasi $(\mathrm{p}=0.037, \mathrm{~b}=-0.177)$ dibandingkan dengan strategi akulturasi multikultural. Namun jika dibandingakan dengan strategi akulturasi asimilasi tidak ada perbedaan yang signifikan dengan strategi akulturasi multikultural $(\mathrm{p}=$
0.723, $\mathrm{b}=0.029$ ). Artinya individu akan memiliki kecenderungan yang sama besar dalam memilih strategi akulturasi asimilasi dengan multikultural ketika individu tersebut mempersepsikan keselarasan budayanya dengan budaya lain.

\section{DISKUSI}

Di dalam penelitian ini peneliti memeriksa peran dari persepsi keselarasan budaya terhadap strategi akulturasi yang dilakukan oleh etnis lokal terhadap etnis Tionghoa di Medan. Hipotesa dalam penelitian ini adalah ada hubungan antara persepsi keselarasan budaya dengan strategi akulturasi, yang mana semakin seseorang mempersepsikan budayanya selaras dengan budaya lain maka individu tersebut akan cenderung untuk melakukan strategi akulturasi yang multikultural ataupun asimilasi dan sebaliknya jika seseorang mempersepsikan budayanya tidak selaras dengan budaya lainnya maka individu tersebut akan cenderung melakukan strategi akulturasi ekslusi ataupun segregasi.

Hasil penelitian ini memperlihatkan bahwa ada hubungan antara persepsi keselarasan budaya dengan strategi akulturasi yang dilakukan sampel dalam penelitian ini. Berdasarkan hasil analisa yang dilakukan maka didapati bahwa semakin individu mempersepsikan budayanya tidak selaras maka semakin individu tersebut cenderung untuk melakukan strategi akulturasi ekslusi ataupun segregasi. Artinya, semakin individu mempersepsikan budayanya tidak selaras maka individu tersebut tidak ingin membangun hubungan dengan individu dari etnis Tionghoa. Hal ini sejalan dengan yang dikemukankan oleh Vaughan (2002) yakni bahwa semakin dianggap berbeda suatu budaya, semakin orang ingin untuk menjaga jarak dari anggota kelompok budaya tersebut. Pendapat ini juga mendukung temuan dalam penelitian ini yang menyatakan bahwa individu memiliki kecenderungan yang sama untuk melakukan strategi akulturasi asimilasi dengan strategi akulturasi multikultural, artinya kedua strategi ini menunjukkan bahwa individu yang 
mempersepsikan budayanya selaras dengan budaya etnis Tionghoa maka individu ingin membangun hubungan dengan individu dari etnis Tionghoa.

Proses adaptasi atau penyesuaian antar dua kelompok yang berbeda dapat terjadi ketika individu mengetahui apa yang perlu diubah oleh individu tersebut (Matsumoto, 2008). Oleh sebab itu, pengenalan dan pemahaman akan budaya kelompok lain juga sangat penting untuk membantu dalam proses interaksi. Hal ini juga menjadi penting bagi etnis lokal untuk mengenal dan memahami budaya dari etnis Tionghoa agar proses adaptasi atau penyesuaian dapat terjadi. Sehingga dari proses pengenalan dan pemahaman terhadap budaya lain akan terbentuk sebuah penilaian terhadap budaya tersebut apakah budaya lokal memiliki keselarasan atau ketidakselarasan dengan budaya Tionghoa.

Penelitian ini juga menemukan bahwa strategi akulturasi yang cenderung dilakukan etnis lokal adalah strategi asimilasi. Sehingga bagi etnis Tionghoa bisa melakukan strategi akulturasi yang dapat membentuk hubungan yang konsensual. Menurut Bourhis et al (1997), akulturasi yang terjadi pada dua kelompok akan menentukan hubungan antar kelompok. Hubungan yang baik adalah hubungan yang konsensual, yakni hubungan ini terjadi apabila individu dari kedua kelompok yakni kelompok lokal dengan kelompok pendatang melakukan strategi akulturasi yang selaras. Salah satunya adalah strategi akulturasi yang sama yakni yang bersifat asimilasi. Jadi ketika penelitian ini menemukan bahwa sampel banyak yang melakukan asimilasi maka etnis Tionghoa disarankan untuk melakukan strategi akulturasi asimilasi.

Latar belakang penelitian ini adalah bahwa masih ada jarak antara etnis lokal dengan etnis Tionghoa hal ini dikarenakan masih adanya persepsi ancaman yang dimilik etnis lokal terhadap keberadaan etnis Tionghoa. Penelitian ini menunjukkan bahwa sampel yang merupakan etnis lokal masih cenderung tidak ingin membangun hubungan dengan etnis Tionghoa. Hal ini dapat kita lihat bahwa ada 55,2 \% dari subjek yang memiliki kecenderungan untuk melakukan strategi akulturasi segregasi dan ekslusi, dimana individu yang melakukan strategi ini masih tidak ingin membangun hubungan dengan individu dari etnis Tionghoa.

\section{KESIMPULAN}

Berdasarkan hasil penelitian hubungan persepsi keselarasan budaya dengan strategi akulturasi , maka dapat ditarik kesimpulan bahwa :

1. Persepsi akan keselarasan budaya memiliki hubungan yang signifikan dengan strategi akulturasi yang dilakukan oleh individu

2. Individu yang mempersepsikan bahwa budaya mereka tidak selaras dengan budaya lain maka individu tersebut cenderung untuk melakukan strategi akulurasi yang ekslusi maupun segregasi.

\section{SARAN}

Berdasarkan hasil penelitian, maka peneliti dapat memberikan saran agar penelitian ini dapat berguna bagi studi lanjutan mengenai persepsi keselarasan budaya dan strategi akulturasi. Beberapa saran antara lain :

\section{Saran Metodologis}

1) Untuk saran kedepan dalam melanjutkan penelitian ini maka dapat diteliti dari segi etnis Tionghoa. Strategi akulturasi yang dilakukan oleh etnis Tionghoa sehingga mendapatkan gambaran yang sesungguhnya bagaimana hubungan antara etnis Tionghoa dengan etnis lokal.

\section{Saran Praktis}

1) Bagi etnis Tionghoa disarankan untuk melakukan strategi akulturasi asimilasi agar terciptanya hubungan yang konsensual dengan etnis lokal di Medan. Dikarenakan dari strategi yang dilakukan etnis lokal adalah strategi akulturasi asimilasi.

2) Bagi etnis lokal dan etnis Tionghoa, setiap individu dari setiap etnis harus mengenal dan memahami budayanya agar lebih mudah 
dalam mempersepsikan apakah budayanya selaras atau tidak selaras dengan budaya lain.

\section{REFERENSI}

Azwar, S. (2001). Metode penelitian. Yogyakarta: Pustaka Belajar.

Azwar, S. (2010). Penyusunan skala psikologi. Yogyakarta: Pustaka Belajar.

Azwar, S. (2010). Reliabilitas dan validitas. Yogyakarta: Pustaka Belajar.

Bangkaru, Mahmud. (2001). Handbook to north sumatra indonesia. Balohann Haloban: Banda Aceh

Bourhis, R.Y., Moise, L.C., Perreault. S., \& Senecal S. (1997). Towards an interactive acculturation: A social psychology approach. International Journal of Psychology, 32 (6), 369-386.

Bourhis, R. Y., Moutreuil, A., Barrette, G., \& Moutaruli, E. (2009). Intergroup misunderstanding: impact of divergent social realities. Acculturation and immigrant host community relations in multikultural setting. Psychology Press : London

Burhan, Omar Khalifa \& Sani, Jefri. (2013). Prasangka terhadap etnis tionghoa di kota medan: peran identitas nasional dan persepsi ancaman. Jurnal Pemikiran \& penelitian Psikologi: Psikologia Vol 18, 25-32

Cameron, K.S., \& Freemen, S.J. (1991). Cultural congruence, strength, and type: Relationships to effectivesness. Research in Organizational Change and Development, 5, 23-55.

Damayanti, Putri. (2005). Tipe prasangka etnis tionghoa terhadap etnis pribumi di kota Medan. Skripsi. Medan: Fakultas Psikologi Universitas Sumatera Utara.

Hadi,Sutrisno. (2000) .Metodologi research. Yogyakarta: Andi Yogyakarta.
Hogg, Michael A. \& Vaughan, Graham M.. (2002). Social psychology, Third Edition. Pearson Prentice Hall

Manurung, Ria \& Sudarwati, Lina. (2005). Realitas pembauran etnis cina di kota Medan. Jurnal Komunikasi Penelitian. Vol 17

Matsumoto, D., \& Juang, L., (2008). Culture \& Psychology $\left(4^{\text {th }} e d\right)$. United State America: Thomson Wadsworth.

Redfield, R., Linton, R., \& Herskovits, M. J. (1936). Memorandum for the study of acculturation. American Anthropologist, 38, 149-152.

Sam, D.L., \& Berry, J.W.(2006). The Cambridge Handbook of Acculturation Psychology. New York: Cambridge University Press.

Suryabrata, S. (2010). Metodologi penelitian. Jakarta: Pt. Raja Grafindo Persada 